\title{
Histopathological Pattern of Salivary Gland Tumors
}

\author{
Shrestha $\mathrm{S}^{1}$, Pandey $\mathrm{G}^{1}$, Pun C.B ${ }^{1}$, Bhatta $\mathrm{R}^{1}$, Shahi $\mathrm{R}^{1}$ \\ ${ }^{I}$ Department of Pathology, B P Koirala Memorial Cancer Hospital, Bharatpur, Nepal
}

\author{
Keywords: \\ Adenoma; \\ Basal cell adenoma; \\ Mucoepidermoid; \\ Pleomorphic adenoma; \\ Salivary gland tumors.
}

\begin{abstract}
Background: The tumors of the salivary glands are uncommon head and neck neoplasms. The aim of this study was to evaluate the relative frequencies, types, site distribution and the histopathological features of salivary gland tumors.

Materials and Methods: This was a retrospective study of 176 cases of salivary gland tumors collected from medical record section and department of pathology at B.P.Koirala Memorial Cancer Hospital from Jan. 2005 to Dec. 2010. Tumors were analyzed based on demographics, anatomic location and histopathological type.

Results: Out of 176 cases, 66 (37.5\%) were benign and 110 (62.5\%) were malignant with M:F ratio of 1.7:1. The mean age observed was 44.76 years with age range of 12 to 75 years. Pleomorphic adenoma was found to be the commonest benign tumor $(72.7 \%)$, followed by Warthin tumor (15.1\%), monomorphic adenoma (3.0 \%) and basal cell adenoma (3.0\%). The mucoepidermoid carcinoma was the most common malignant tumor $(38.1 \%)$, followed by adenoid cystic carcinoma $(25.4 \%)$, acinic cell carcinoma (10.9\%), adenocarcinoma NOS (6.3\%), carcinoma ex pleomorphic adenoma (5.4\%) and unclassified malignant tumor $(4.5 \%)$. Parotid was the most common site for the location of tumors (70.4\%) followed by submandibular (19.3\%) and minor salivary glands $(10.2 \%)$.
\end{abstract}

Conclusion: Pleomorphic adenoma was the commonest salivary gland tumor observed in both sexes. Mucoepidermoid carcinoma was the most common malignant salivary gland tumor. The parotid gland was the most common site of origin in both benign and malignant tumors.

\section{INTRODUCTION}

Salivary gland tumours are rare, comprising approximately $3 \%$ to $10 \%$ of the neoplasm of the head and neck region. ${ }^{1}$,

${ }^{2}$ The global incidence of these tumours is $0.4-13.5$ per 100,000 persons annually. ${ }^{3-5}$ Approximately $80 \%$ of the salivary gland tumours are found in the parotid gland and 10 to $15 \%$ in the submandibular gland. ${ }^{6}$ Around $80 \%$ parotid tumours and $50 \%$ of submandibular tumours are benign. ${ }^{7}$ Salivary gland tumours were observed in all ages

\author{
Correspondence: \\ Dr. Sadina Shrestha, $M D$ \\ Consultant Pathologist, Department of Pathology, \\ B. P. Koirala Memorial Cancer Hospital, Bharatpur, Chitwan, Nepal \\ Email: sadina_shrestha@yahoo.com
}

but the highest incidence is observed in $3^{\text {th }}$ and $4^{\text {th }}$ decades for benign tumours and $4^{\text {th }}$ and $5^{\text {th }}$ decades for malignant tumours. ${ }^{8}$ The aim of this study was to recognize various histomorphology of salivary gland tumours, their frequency, age and site distribution.

\section{MATERIALS AND METHODS}

The data for the present study was obtained from the medical record section and department of pathology from January 2005 to December 2010. Information regarding age, gender, tumor location and tumor size were determined for each salivary tumor type. The frequencies of different benign and malignant salivary tumors in both major and 
minor glands were identified. All the biopsy specimens were fixed in $10 \%$ formol-saline, then processed into paraffin embedded sections and stained with hematoxylin and eosin (H\&E). The histopathology of all tumors was reviewed and classified according to the World Health Organization (WHO) histological typing of salivary gland tumors.

\section{RESULTS}

Out of 34,978 biopsies reported at B.P.Koirala Memorial Cancer Hospital during the study perioid, 176 cases were related to salivary gland tumor. Of the 176 cases, 66 $(37.5 \% \%)$ were benign and $110(62.5 \%)$ were malignant, representing a ratio of 1:1.6 respectively. Male were more affected by both benign and malignant tumors. The highest incidence for benign tumors was in the $3^{\text {rd }}$ and $4^{\text {th }}$ decade, where as for malignant tumor it was the $4^{\text {th }}$ and $5^{\text {th }}$ decade of life. The mean age observed for all salivary gland tumors was 44.76 years with age range of 12 to 75 years (Table 1 ). The most common site of occurrence for both benign and malignant tumors was parotid gland (Table 2). Distribution of benign salivary gland tumors are shown in Table 3. Of
Table 1: Age wise distribution of salivary glands tumors

\begin{tabular}{cccc}
\hline $\begin{array}{c}\text { Age } \\
\text { Distribution }\end{array}$ & $\begin{array}{c}\text { Benign } \\
\text { tumors }\end{array}$ & $\begin{array}{c}\text { Maligant } \\
\text { tumors }\end{array}$ & $\begin{array}{c}\text { Total No. of } \\
\text { Patient }\end{array}$ \\
\hline$<20$ & 4 & 6 & 10 \\
\hline $21-30$ & 12 & 10 & 22 \\
\hline $31-40$ & 22 & 16 & 38 \\
\hline $41-50$ & 10 & 36 & 46 \\
\hline $51-60$ & 8 & 14 & 22 \\
\hline $61-70$ & 6 & 18 & 24 \\
\hline$>70$ & 4 & 10 & 14 \\
\hline
\end{tabular}

benign salivary gland tumors, pleomorphic adenoma (fig. 1) was the most common histologic type followed by warthin's tumor (fig. 2).

Distribution of malignant tumors in salivary glands is shown in Table 4. Mucoepidermoid carcinoma (38.1\%) was most common among the malignant salivary gland tumors. Parotid was the most common site of occurrence

Table 2: Distribution of tumor according to sex and site

\begin{tabular}{lccccccc}
\hline & & \multicolumn{2}{c}{ Parotid gland } & \multicolumn{2}{c}{ Submandibular gland } & \multicolumn{2}{c}{ Minor salivary gland } \\
\hline Sex & Total & Benign & Malignant & Benign & Malignant & Benign & Malignant \\
Male & $112(63.6 \%)$ & $32(48.5 \%)$ & $46(41.8 \%)$ & $6(9.0 \%)$ & $16(14.5 \%)$ & $3(4.5 \%)$ & $9(8.1 \%)$ \\
Female & $64(36.4 \%)$ & $20(30.3 \%)$ & $26(23.6 \%)$ & $4(6.0 \%)$ & $8(7.2 \%)$ & $1(1.5 \%)$ & $5(4.5 \%)$ \\
\hline
\end{tabular}

Table 3: Distribution of benign tumors in salivary glands

\begin{tabular}{lcccc}
\hline Tumor type & Parotid glands & Submandibular & Minor salivary glands & Total \\
\hline Pleomorphic adenoma & $36(54.5 \%)$ & $8(12.1 \%)$ & $4(6.0 \%)$ & $48(72.7 \%)$ \\
Warthin's tumor & $8(12.1 \%)$ & $2(3.0 \%)$ & - & $10(15.1 \%)$ \\
Monomorphic adenoma & $2(3.0 \%)$ & - & - & $2(3.0 \%)$ \\
Basal cell adenoma & $2(3.0 \%)$ & - & - & $2(3.0 \%)$ \\
Myoepithelioma & $1(1.5 \%)$ & - & - & $1(1.5 \%)$ \\
Schwannoma & $2(3.0 \%)$ & - & - & $2(3.0 \%)$ \\
Lipoma & $1(1.5 \%)$ & & $1(1.5 \%)$ \\
\hline
\end{tabular}

Table 4: Distribution of malignant tumours in salivary glands

\begin{tabular}{|c|c|c|c|c|}
\hline Tumor type & Parotid glands & $\begin{array}{l}\text { Submandibular } \\
\text { glands }\end{array}$ & Minor salivary gland & Total \\
\hline Mucoepidermoid carcinoma & $26(23.6 \%)$ & $6(5.4 \%)$ & $10(9.0 \%)$ & $42(38.1 \%)$ \\
\hline Adenoid cystic carcinoma & $10(9.0 \%)$ & $14(12.7 \%)$ & $4(3.6 \%)$ & $28(25.4 \%)$ \\
\hline Acinic cell carcinoma & $8(7.2 \%)$ & $4(3.6 \%)$ & - & $12(10.9 \%)$ \\
\hline Adenocarcinoma NOS & $7(6.3 \%)$ & - & - & $7(6.3 \%)$ \\
\hline Carcinoma Ex pleomorphic adenoma & $6(5.4 \%)$ & - & - & $6(5.4 \%)$ \\
\hline Unclassified malignant tumor & $5(4.5 \%)$ & - & - & $5(4.5 \%)$ \\
\hline Squamous cell carcinoma & $4(3.6 \%)$ & - & - & $4(3.6 \%)$ \\
\hline Basal cell carcinoma & $2(1.8 \%)$ & - & - & $2(1.8 \%)$ \\
\hline Polymorphous low grade adenocarcinoma & $2(1.8 \%)$ & - & - & $2(1.8 \%)$ \\
\hline Metastatic undifferentiated carcinoma & $2(1.8 \%)$ & - & - & $2(1.8 \%)$ \\
\hline
\end{tabular}




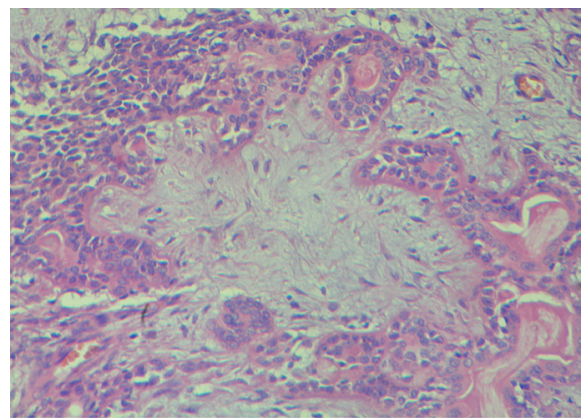

Figure 1: Pleomorphic adenoma showing both epithelial and mesenchymal components (HE stain, X200).

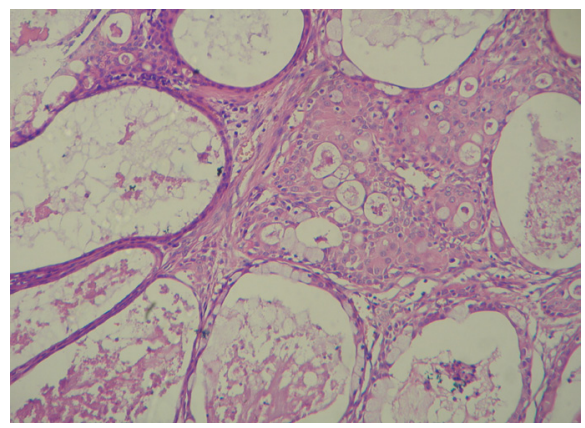

Figure 3: Low-grade mucoepidermoid carcinoma showing glandular spaces with mucous secreting cells and intermediate cells (HE stain, X200).

for mucoepidermoid carcinoma followed by minor salivary glands and submandibular gland.

Submandibular gland was the most common site of occurrence for adenoid cystic carcinoma (fig.4). Parotid was the third most common site of occurrence for acinic cell carcinoma (7.2\%) followed by submandibular gland (3.6 $\%)$. All cases of carcinoma ex pleomorphic adenoma, basal cell carcinoma, adenocarcinoma, squamous cell carcinoma, metastatic undifferentiated carcinoma involved only the parotid gland.

The commonest malignant tumor of parotid $(23.6 \%)$ and the minor salivary glands $(9.0 \%)$ was mucoepidermoid carcinoma. In the submandibular gland the most common malignant salivary gland tumor was adenoid cystic carcinoma $(12.7 \%)$.

\section{DISCUSSION}

In the present study of 176 cases of salivary gland tumors, $66(37.5 \%)$ were benign and $110(62.5 \%)$ were malignant. However; other studies have noted predominance of benign tumors over the malignant ones. ${ }^{9-11}$ Since our study was based at cancer hospital where diagnosed malignant cases are referred for further management; it may have led to predominance of malignant ones.

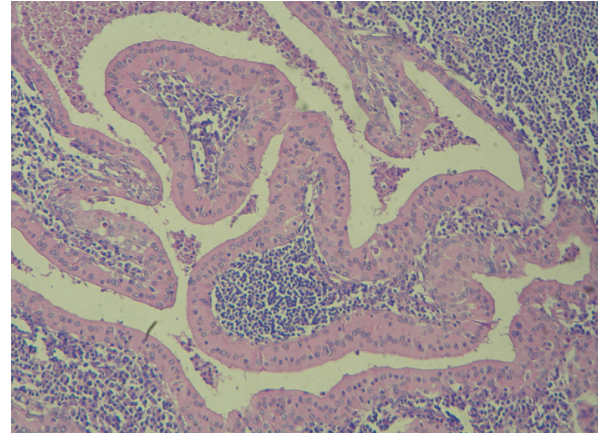

Figure 2: Warthin's tumour. The papillary projection exhibits oncocytic lining cells and an underlying lymphoid stroma (HE stain, X 200).

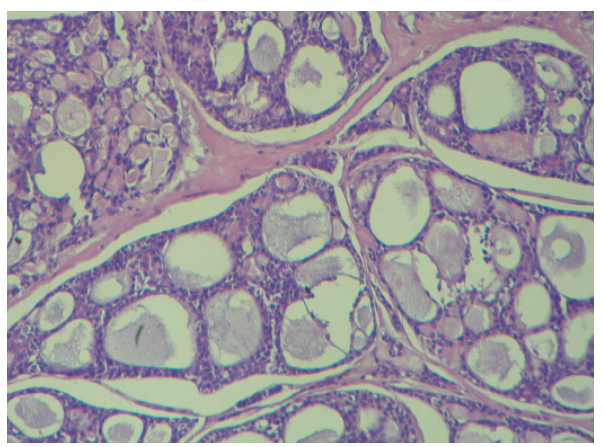

Figure 4: Typical adenoid cystic carcinoma showing cribriform pattern (HE stain, X 200).

In the present series mean age observed was 46.7 years with an age range of 12 to 75 years. Benign salivary gland tumors were more common in age group of 31 to 40 years and the peak age incidence observed for malignant salivary gland tumors was 41 to 50 years. Chatterjee et al. observed large number of benign cases in third decade followed by fourth decade. ${ }^{12}$ Malignancy reported in his study was predominant in the $5^{\text {th }}$ decade.

In the present study a male preponderance was noted with a male: female ratio of 1.7:1. This is in agreement with series reported by Potdar GG et al ${ }^{13}$ Spiro et $\mathrm{a}^{14}$. However; this was in contrast to the series reported by Dandapat et $\mathrm{al}^{15}$ and Rewsuwan et $\mathrm{al}^{16}$ who reported a female preponderance in their series. Parotid was the commonest site of neoplasia $(70.5 \%)$ in this series followed by submandibular gland $(19.3 \%)$ and minor salivary glands $(10.2 \%)$. This is in conformity with other workers, viz., Gore et al. ${ }^{17}$

In the majority of case series, Pleomorphic adenoma was the most common benign salivary gland tumor encountered in parotid, submandibular and minor salivary glands. ${ }^{12,13,18-20}$ Similar findings were observed in the present study where pleomorphic adenoma was the most common benign salivary gland tumor at all locations. Out of total 48 pleomorphic adenomas in our study, majority occurred in the parotid gland $(\mathrm{N}=36 ; 54.5 \%)$ followed by submandibular gland 
$(\mathrm{N}=8 ; 12.1 \%)$ and minor salivary glands $(\mathrm{N}=4 ; 6.0 \%)$. Out of all reported cases of pleomorphic adenoma, 32 were males and 16 were females with a male to female ratio of $2: 1$. Potdar $\mathrm{GG}^{13}$ reported 183 cases of pleomorphic adenomas, out of which 101 were involving parotid gland. Warthin tumor (14.29\%) was the 2nd commonest benign tumors as quoted by Chung et al. ${ }^{21}$ Eight cases (12.1\%) of Warthin tumor were involved in the parotid gland followed by $(\mathrm{N}=2 ; 3.0 \%)$ of in submandibular gland which is similar to what has been reported by Eveson et al. ${ }^{22}$

One case of lipoma was seen in our study. Literature review reveals that these are rare neoplasms of parotid, however occasional cases have been reported in the parotid gland..$^{23}$ Schwannoma presenting as primary salivary gland neoplasm is a recognized entity. ${ }^{24}$ These are thought to arise from the radicals of facial nerve. We observed two cases $(3.0 \%)$ of schwannoma, all affecting parotid gland.

Mucoepidermoid carcinoma was the most common malignant salivary gland tumor of parotid constituting $26(23.6 \%)$ of all malignant salivary gland tumors in the present series. Mucoepidermoid carcinoma was reported to be the most common malignant salivary gland tumor of parotid by Richardson et $\mathrm{al}^{18}$ and Spiro et al. ${ }^{14}$ In our study mucoepidermoid carcinoma was more common in parotid gland $(\mathrm{N}=26 ; 23.6 \%)$ followed by minor salivary glands $(\mathrm{N}=10 ; 9.0 \%)$ and submandibular gland $(\mathrm{N}=6 ; 5.4 \%)$. Richardson et al. ${ }^{19}$ reported 61 cases of mucoepidermoid carcinoma and parotid $(\mathrm{N}=52)$ was reported to be the most common site of occurrence followed by minor salivary glands $(\mathrm{N}=6)$ and submandibular gland $(\mathrm{N}=3)$.

The most common malignant salivary gland tumor observed in submandibular salivary gland was adenoid cystic carcinoma accounting for (12.7\%) of all malignant salivary gland tumors. Similarly, Potdar et $\mathrm{al}^{13}$, Richardson et $\mathrm{al}^{18}$, and Rewsuwan et $\mathrm{al}^{16}$ also found adenoid cystic carcinoma to be the most common malignant tumor of submandibular glands. Vergas et al ${ }^{19}$, reported five cases of adenoid cystic carcinoma in their series accounting for $4 \%$ of all cases or $20 \%$ of malignant tumors. It was also reported to be the second most common malignant salivary gland tumor in their series. In contrast to the present study, Lima et $\mathrm{al}^{25}$ and Rewsuwan et $\mathrm{al}^{16}$ reported adenoid cystic carcinoma to be the most common malignant salivary gland tumor in their series.

Carcinoma ex pleomorphic adenoma is an infrequent aggressive malignancy that is believed to evolve from a pre-existing benign adenoma. It accounts for 3.6\% (range, $0.9 \%-14 \%$ ) of all salivary neoplasms and for $11.7 \%$ (range, $2.8 \%-42.4 \%$ ) of salivary malignancies. ${ }^{26}$ We found 6 cases (5.4\%) of carcinoma ex pleomorphic adenoma of the parotid gland.

Polymorphous low grade adenocarcinoma(PLA) occurs almost exclusively in minor salivary gland and its origin in a major salivary gland is considered rare. Although several report have described PLGA of the parotid gland..$^{27,28} \mathrm{We}$ found two cases $(3.0 \%)$ of PLGA in parotid gland.

Primary squamous cell carcinoma of salivary gland is rare. Batsakis et al indicated that the true incidence to be $0.3 \%$ to $1.5 \% .^{29}$ We found only 4 (3.6\%) of squamous cell carcinoma in parotid gland in our series.

\section{CONCLUSION}

Salivary gland tumors are rare. Male and the parotid gland were the most affected and pleomorphic adenoma was the most frequent lesion, followed by mucoepidermoid carcinoma and adenoid cystic carcinoma.

\section{REFERENCES}

1. Ansari MH. Salivary gland tumors in an Iranian population: a retrospective study of 130 cases. Journal of Oral and Maxillofacial Surgery 2007;65:2187-94. http://dx.doi.org/10.1016/j.joms.2006.11.025

2. Jones AV, Craig GT, Speight PM, Franklin CD. The range and demographics of salivary gland tumours diagnosed in a UK population. Oral Oncol 2008;44:407-17. CrossRef

3. Ma'aita JK, Al-Kaisi N, Al-Tamimi S, and Wraikat A. Salivary gland tumors in Jordan: a retrospective study of 221 patients. Croat Med J 1999;40:539-42. PMid:10554362

4. Jaber MA. Intraoral minor salivary gland tumors: a review of 75 cases in a Libyan population. Int J Oral Maxillofac Surg 2006;35:150-4. CrossRef

5. Tian Z, Li L, Wang L, Hu Y, and Li J. Salivary gland neoplasms in oral and maxillofacial regions: a 23-year retrospective study of 6982 cases in an eastern Chinese population. Int J Oral Maxillofac Surg 2010;39:235-42. CrossRef

6. Bataskis J. G. and Regezi J. A. The pathology of head and neck tumors: salivary glands, part 1. Head Neck Surg 1978;1:59-68. CrossRef

7. Paparella's Otolaryngology: Vol. III, 3rd Edition, W. B. Saunders. 1991; 20: 2099pp.

8. Ahrnad S, Lateef M, Ahmad R. Clinicopathological study of primary salivary gland tumors in Kashmir. JK-Practitioner 2002;9:231-3.

9. Nepal A, Chettri ST, Joshi RR, Bhattarai M, Ghimire A, Karki S; Primary Salivary Gland Tumors in Eastern Nepal Tertiary Care Hospital. J Nepal Health Res Counc 2010;8:31-4. PMid:21879011

10. Naeem Sultan A, Nawaz A, Rajput S, Ikram M. Parotidectomy: A Review of 112 Patients Treated at a TeachingHospital in Pakistan. 
Asian Pac J Cancer Prev 2010;11:1111-3.

11. Moghadam SA, Moghadam FA, Dadfar M. Epithelial Salivary Gland Tumors in Ahvaz, Southwest of Iran. J Dent Res Dent Clin Dent Prospect 2010;4:120-23.

12. Chatterjee MT and Panda PK. A Pathological study of benign and malignant tumors of salivary glands; MJAFI 2000;56:282-6.[URL: http://medind.nic.in/maa/t00/i4/maat00i4p282.pdf]

13. Potdar GG, Paymaster JC. Tumors of salivary glands. Am J Surg 1969;118:440-7. CrossRef

14. Spiro RH, Huvos AG, Strong EW. Cancer of the parotid gland: a clinicopathologic study of 288 primary cases. Am J Surg 1975;130:452-9. CrossRef

15. Dandapat MC, Rath BK, Patnaik BK, Dash SN. Tumors of salivary glands. Indian J Surg 1991;53:200.

16. Rewsuwan S, Settakorn J and Mahanupab P. Salivary gland tumors in Maharaj Nakorn Chiang Mai Hospital: A retrospective study of 198 cases. Chiang Mai Med Bull 2006;45:45- 53.

17. Gore DO, Annamunthodo H, Harland A. Tumors of salivary gland origin. Surg Gynecol Obstet 1964; 119:1290-6. PMid:14227757

18. Richardson GS, Dickason WL, Gaisford JC, et al. Tumors of salivary glands; An analysis of 752 cases. Plastic Reconstr Surg 1975;55:131. CrossRef

19. Vergas PA, Gerhard R, Vergilius J. F, Filiho A and de Castro IV. Salivary gland tumors in Brazillian population: A retrospective study of 124 cases. Rev. Hosp. Clin. Fac. Med. S. Paulo 2002;57:271-6.

20. Nagarkar NM, Bansal S, Dass A, Singhal SK, Mohan H. Salivary gland tumors- Our Experience. Indian J Otolaryngol Head Neck Surg 2004;56:32-4.

21. Chung YF, Khoo ML, Heng MK, Hong GS, Soo KC. Epidemiology of Warthin's tumour of the parotid gland in an Asian population. Br J Surg 1999;86:661-4. PMid:10361190

22. Eveson JW, Cawson RA. Warthin's tumor (cystadenolymphoma) of salivary glands. A clinicopathologic investigation of 278 cases. Oral Surg Oral Med Oral Pathol 1986;61:256-62. CrossRef

23. Muzaffar S, Kayani N, Hasan SH. Partoid gland lipoma: a rare entity. J Pak Med Assoc 1996;46:262-3. PMid:9000822

24. Katz AD, Passy V, Kaplan L. Neurogenous neoplasms of major nerves of face and neck. Arch. Surg 1971;103:51-56. CrossRef

25. Lima SS, Soares AF, de Amorim RF, Freitas RA. Epidemiologic profile of salivary gland neoplasms: analysis of 245 cases. Braz J Otorhinolaryngol 2005;71:335-40. PMid:16446938

26. Olsen KD, Lewis JE. Carcinoma ex pleomorphic adenoma: a clinicopathologic review. Head Neck 2001;23:705-12. CrossRef

27. Arathi N, Bage AM. Polymorphous low-grade adenocarcinoma of parotid gland: A rare occurrence. Indian J Pathol Microbiol 2009;52:103-5. CrossRef

28. Katoh T, Yoshihara T, Kaneko $\mathrm{T}$ et al. A case of polymorphous adenocarcinoma in the right parotid gland. Gan No Rinsho1985;31:861 - 4. PMid:4032762

29. Batsakis JG, Mc Clatchey KD, Johns M. Primary squamous cell carcinoma of the parotid gland. Arch Otolaryngol. 1976; 102:355- 7. CrosRef 